Article

\title{
Immobilizing Laccase on Modified Cellulose/CF Beads to Degrade Chlorinated Biphenyl in Wastewater
}

\author{
$\mathrm{Na} \mathrm{Li}^{1,2,3}$, Quiyang $\mathrm{Xia}^{3}$, Yuan $\mathrm{Li}^{3}{ }^{[}{ }^{\mathbb{D}}$, Xiaobang Hou ${ }^{4}$, Meihong Niu ${ }^{1}$, Qingwei Ping ${ }^{1}$ \\ and Huining Xiao ${ }^{3, *}$ \\ 1 Liaoning Province Key Laboratory of Plup and Papermaking Engineering, Dalian Polytechnic University, \\ Dalian 116034, China; lina@dlpu.edu.cn (N.L.); niumh@dlpu.edu.cn (M.N.); pingqw@dlpu.edu.cn (Q.P.) \\ 2 Key Laboratory of Pulp and Paper Science \& Technology of Ministry of Education/Shandong Province, \\ Qilu University of Technology, Jinan 250353, China \\ 3 Department of Chemical Engineering, University of New Brunswick, Fredericton, NB E3B 5A3, Canada; \\ qxia2@unb.ca (Q.X.); yli7@unb.ca (Y.L.) \\ 4 Department of Environment Science \& Engineering, North China Electric Power University, \\ Baoding 071003, China; xhou1@unb.ca \\ * Correspondence: hxiao@unb.ca; Tel.: +1-506-4533532
}

Received: 7 June 2018; Accepted: 11 July 2018; Published: 19 July 2018

\begin{abstract}
Novel modified cellulose/cellulose fibril (CF) beads (MCCBs) loaded with laccase were prepared to degrade polychlorinated biphenyls (PCBs) in wastewater. The proper porous structure in MCCBs was achieved by introducing nano $\mathrm{CaCO}_{3}$ (as a pore forming agent) in cellulose/CF (CCBs) beads during the preparation process. Cellulose/CF composite beads were modified by maleic anhydride to introduce carboxyl groups. Laccase was immobilized on the MCCBs through electrostatic adsorption and covalent bonding. The effects of $\mathrm{pH}$, laccase concentration and contact time on immobilization yields and recovered activity were investigated. The best conditions were $\mathrm{pH} 4$, concentration $16 \mathrm{~g} / \mathrm{L}$ and contact time $3 \mathrm{~h}$. The immobilized laccase under these conditions showed a good performance in thermal and operational stability. The laccase immobilized on MCCB beads can remove $85 \%$ of $20 \mathrm{mg} / \mathrm{L}$ 4-hydroxy-3,5-dichlorobiphenyl (HO-DiCB) in wastewater. The results demonstrated that MCCBs, as a new type of green-based support, are very promising in material immobilizing laccase. This technology may be of potential advantage for the removal of polychlorinated biphenyls in wastewater from an environmental point of view.
\end{abstract}

Keywords: chlorinated biphenyl pollutants; cellulose/CF beads; adsorption; laccase immobilization

\section{Introduction}

Polychlorinated biphenyls (PCBs) are a class of materials commonly used in various commercial products. These materials can cause environmental contaminations both due to its toxicity and stability against degradation in soil and water [1], and are included in the Persistent Organic Pollutions (POP) group [2]. In the past decade, great attention has been focused on the degradation of PCBs due to their toxicity and bioaccumulation [3]. Several methods have been developed to degrade PCBs, including the degradation induced by laccase, which was considered as an efficient route to solve the problem because the phenolic compounds were the major substrates of laccase $[4,5]$. Although laccase showed a good performance in the removal of PCBs [6], some negative characteristics, such as instability caused by thermal and $\mathrm{pH}$ denaturation, poor reusability and inactivation, have hindered the application of laccase in water treatment [7-9]. In order to overcome such shortcomings, enzyme immobilization, 
one of the most promising techniques for highly efficient and economically competent biotechnological processes [10], has been developed.

Laccase immobilization has been researched for a number of years and several materials have been studied as supports [11]. The materials used as supports are often classified into two categories: inorganic materials and organic materials. Among the most abundant organic materials, cellulose is considered promising due to its renewability, easy biodegradation and low contaminant risk to the environment $[12,13]$. In addition, various reactive groups can be easily introduced onto the cellulose surface $[14,15]$. Such properties make cellulose suitable for the immobilization of laccase [16]. Immobilization of laccase on bacterial cellulose [17,18] and cellulose nanofibers has been reported [19]. However, in order to facilitate the application of immobilized laccase, other factors should also be considered, such as shape, distribution, pore size and expandability of laccase [20].

In this work, a cellulose-based porous bead MCCBs was used as a novel support for immobilizing laccase. As green and degradable materials, the cellulose and cellulose filament (CF) are chosen to produce the composite-type bioadsorbent for improved mechanical properties and durability. During the beads formation process, $\mathrm{CF}$ was added as a reinforcement, and proper pore structure was generated using nano $\mathrm{CaCO}_{3}$ as a pore forming agent; additional $-\mathrm{COOH}$ groups were introduced via grafting maleic anhydride. The beads with porous structure and functional groups can not only adsorb but also be covalently bonded with laccase. The effects of the immobilization conditions on the immobilization yield and recovered activity were investigated. In addition, 4-hydroxy-3,5-dichlorobiphenyl (HO-DiCB) was used as a model of PCBs to test the ability of immobilized laccase for the removal of PCBs in wastewater.

\section{Materials and Methods}

\subsection{Materials}

Disodium hydrogen phosphate dodecahydrate $\left(\mathrm{Na}_{2} \mathrm{HPO}_{4} \cdot 12 \mathrm{H}_{2} \mathrm{O}\right)$, anhydrous citric acid, sodium hydroxide and 2,2'-azino-bis(3-ethylbenzothiazoline-6-sulfonic acid) (ABTS), coomassie brilliant blue (CBB), $95 \%$ ethyl alcohol, $85 \%$ phosphoric acid $\left(\mathrm{H}_{3} \mathrm{PO}_{4}\right)$, sodium chloride $(\mathrm{NaCl})$, and bovine serum albumin (BSA) were all purchased from Sigma chemical (Oakville, ON, Canada) and were analytical grade. HO-DiCB was purchased from AccuStandard, New Haven, CT, USA. Laccase (800 U/g) was kindly donated by a Taiwan biological company in Taipei, Taiwan. CF was kindly donated by FPInnovations Canada (Pointe Claire, Montreal, QC, Canada), which was in micro-range (lengths $50-800 \mu \mathrm{m}$, surface area $>80 \mathrm{~m}^{2} / \mathrm{g}$ ). Filter paper is Fisher brand ${ }^{\circledR}$ (Qualitative P4, porosity: Medium-Fine; Flow Rate:Slow, Fisher Scientific, Ottawa, ON, Canada).

\subsection{Preparation and Modification of the Cellulose/CF Beads}

Cellulose beads were prepared using a previously developed method [21,22]. Briefly, $2 \mathrm{~g}$ of filter paper was dissolved in $\mathrm{NaOH}(7 \mathrm{wt} \%) /$ Urea $\left(12 \mathrm{wt} \%\right.$ ) aqueous solution at $-10{ }^{\circ} \mathrm{C}$, forming a $4 \%$ cellulose solution. $0.8 \mathrm{~g}$ nano $\mathrm{CaCO}_{3}$ powder and $2 \mathrm{~g} \mathrm{CF}$ (as a reinforcement) were added into the cellulose solution and the mixture was injected into $1 \mathrm{M} \mathrm{HCl}$ solution through a syringe. The $\mathrm{CaCO}_{3}$ reacted with $\mathrm{HCl}$, releasing $\mathrm{CO}_{2}$ that created a porous structure within dissolved cellulose matrix. Finally, the porous Cellulose/CF composite beads [23] were separated from the suspension by filtration and dried at $50{ }^{\circ} \mathrm{C}$ in a vacuum oven overnight.

To modify Cellulose/CF beads, $2 \mathrm{~g}$ of Cellulose/CF beads were added into $20 \mathrm{~mL}$ of $10 \mathrm{wt} / \mathrm{v} \%$ maleic anhydride solution in acetone. The reaction was kept for $1 \mathrm{~h}$ at room temperature. Then, the mixture was put in $50{ }^{\circ} \mathrm{C}$ vacuum oven for $1 \mathrm{~h}$ to evaporate the acetone. After evaporation, the residual solids were heated in $100{ }^{\circ} \mathrm{C}$ vacuum oven for $3 \mathrm{~h}$ and modified Cellulose/CF (MCCBs) were obtained. 


\subsection{Characterization of $M C C B s$}

The chemical bonds of MCCBs were analyzed with Fourier Transform Infrared Spectroscopy (FTIR), and the amount of the carboxyl groups $(\mathrm{C}=\mathrm{O})$ on the MCCBs was evaluated using an acid-base titration method. A scanning electron microscopy (SEM) was used to visualize the surface morphology of MCCBs (JEOL 6400, JEOL, Tokyo, Japan). The MCCBs were first inbeded in epoxy resin and then split in half in order to achieve the cross-section. The sliced samples were coated with gold prior to the measurement.

\subsection{Determination of Laccase Activity}

A $0.4 \mathrm{mM}$ ABTS solution was used as substrate to measure the enzyme activity of free and immobilized laccase and all operations were proceeded at $25 \pm 1{ }^{\circ} \mathrm{C}$. Free enzyme activity was determined by adding $0.1 \mathrm{~mL}$ laccase solution to $1.9 \mathrm{~mL}$ ABTS solution and measuring the absorbance of the mixture solution at $420 \mathrm{~nm}\left(\varepsilon_{420}=36,000 \mathrm{M}^{-1} \mathrm{~cm}^{-1}\right)$ [24]. A UV-Vis spectrophotometer (Genesys 10-S, Thermo Electron Corporation, Waltham, MA, USA) was used to measure the increase of the absorbance for $5 \mathrm{~min}$ and the absorbance data were recorded per $30 \mathrm{~s}$. Recorded data were plotted into kinetic curve and the activity was determined by calculating the slope of initial linear portion of the curve. Unit of free enzyme activity was expressed in $\mathrm{U} / \mathrm{L}$ and one $\mathrm{U}$ was defined as the amount of free enzyme required to catalyze $1 \mu \mathrm{mol}$ of substrate per minute.

To measure immobilized enzyme activity, $0.1 \mathrm{~g}$ of laccase-loaded support was put in $2 \mathrm{~mL}$ of ABTS and $7.0 \mathrm{~mL}$ of citrate-phosphate buffer mixed solution at $25 \pm 1{ }^{\circ} \mathrm{C}$. For every two minutes, $2 \mathrm{~mL}$ of the mixed solution was withdrawn to analyze absorbance by the UV-Vis spectrophotometer at $420 \mathrm{~nm}$ and was rapidly returned back to reactor after measurement. U/g was used to express the immobilized enzyme activity per unit gram of support, given that enzyme weight is negligible.

\subsection{Immobilization of Laccase}

The conditions for immobilizing laccase on MCCBs were optimized first. A total of $10 \mathrm{mg}$ of MCCBs were incubated in $10 \mathrm{~mL}$ of laccase solution containing $0.5-32 \mathrm{~g} / \mathrm{L}$ of enzyme in a $20 \mathrm{~mL}$ bottle at varying $\mathrm{pH}$ from 3.0 to 7.0 in the room temperature. The bottles with the solutions were stirred on a magnetic stirrer. At the optimized conditions of $\mathrm{pH}$ and enzyme concentration, the effect of contact time was evaluated in the range from $30 \mathrm{~min}$ to $8 \mathrm{~h}$. After immobilization, the support was collected by filtration and washed three times with $0.1 \mathrm{M}$ of phosphate buffer $(\mathrm{pH} 4.0)( \pm 100 \mathrm{~mL}$ each wash). The filtrate was kept for enzyme activity measurements. The immobilized enzyme activity was measured as described above. The immobilization yield was calculated as follows:

$$
\text { immobilization }=\frac{\text { Originalenzymeconcentration-Enzymeconcentrationafterimmobilization }}{\text { Originalenzymeconcentration }} \times 100
$$

Measurement of enzyme concentration was according to the Bradford method [25]. The recovered activity was calculated using the following equation:

$$
\text { recoveredactivity }=\frac{\text { immobilizedenzymeactivity }}{\text { activityofsameamountoffreeenzyme }} \times 100
$$

An electron dispersive spectroscopy (EDS) (JEOL 2011, JEOL, Tokyo, Japan) was used to perform an elemental analysis of the immobilized laccase MCCBs.

\subsection{Thermal and Operational Stability of Immobilized Laccase}

The enzyme activities of the free and immobilized laccase were measured to evaluate the thermal stability in $\mathrm{pH} 4.0$ buffer solution at $60^{\circ} \mathrm{C}$. A water bath with temperature controller was used in this experiment. The enzyme activities were measured each hour and the experiment lasted for $6 \mathrm{~h}$. The initial activity was set as $100 \%$. 
A total of $0.1 \mathrm{~g}$ of laccase-loaded MCCBs was used to measure the operational stability in $2 \mathrm{~mL}$ ABTS and $7 \mathrm{~mL}$ citrate-phosphate buffer at $\mathrm{pH} 4.0$ and $25 \pm 1{ }^{\circ} \mathrm{C}$. The stability experiments were operated for 10 cycles. The immobilized laccase enzyme activity was measured at each cycle and the supports were separated by filtration and washed twice by $30 \mathrm{~mL}$ buffer before next cycle.

\subsection{Degradation of the PCBs}

In order to prepare a HO-DiCB aqueous solution, $10 \mathrm{mg}$ of HO-DiCB was reacted with $1.7 \mathrm{mg}$ of $\mathrm{NaOH}$ in $50 \mathrm{~mL}$ of deionized water; the final volume was adjusted to $250 \mathrm{~mL}$. The degradation efficiency was determined by adding $50 \mathrm{mg}$ immobilized laccase in $10 \mathrm{~mL}$ of HO-DiCB aqueous solution and $10 \mathrm{~mL}$ of $\mathrm{pH} 4.0$ phosphate buffer at room temperature. The reaction lasted for $8 \mathrm{~h}$ and the concentration of HO-DiCB was measured each hour. A control experiment, in which $50 \mathrm{mg}$ CCBs without immobilized laccase was reacted with another $10 \mathrm{~mL}$ of PCBs model solution under the same conditions, was carried out simultaneously. The concentration of HO-DiCB aqueous solution was determined by standard curve of absorption at $260 \mathrm{~nm}$. Degradation yield (\%) was defined as follows:

$$
\text { degradation }=\frac{\text { original HO }- \text { DiCBamount }- \text { finalHO }- \text { DiCBamount }}{\text { original HO }- \text { DiCBamount }} \times 100
$$

\subsection{Statistical Analysis}

For each assay duplicate or triplicate measurements were conducted.

\section{Results and Discussion}

\subsection{Characterization of $M C C B s$}

Figure 1 presents the FTIR spectra of CCBs and MCCBs. The peak at $3340 \mathrm{~cm}^{-1}$ is assigned to -OH group, and the strong absorption at $2906 \mathrm{~cm}^{-1}$ is due to $\mathrm{C}-\mathrm{H}$ stretching from cellulose. When the FTIR spectra of MCCBs were compared to that of CCBs, there was a strong absorption peak at $1718 \mathrm{~cm}^{-1}$, which corresponds to the $\mathrm{C}=\mathrm{O}$ bonds. The FTIR spectra showed that the maleic anhydride was grafted onto the cellulose surface successfully. In order to determine the amount of the carboxyl groups, a titration method was used and the concentration of carboxyl groups of MCCBs was $0.519 \mathrm{mmol} / \mathrm{g}$.
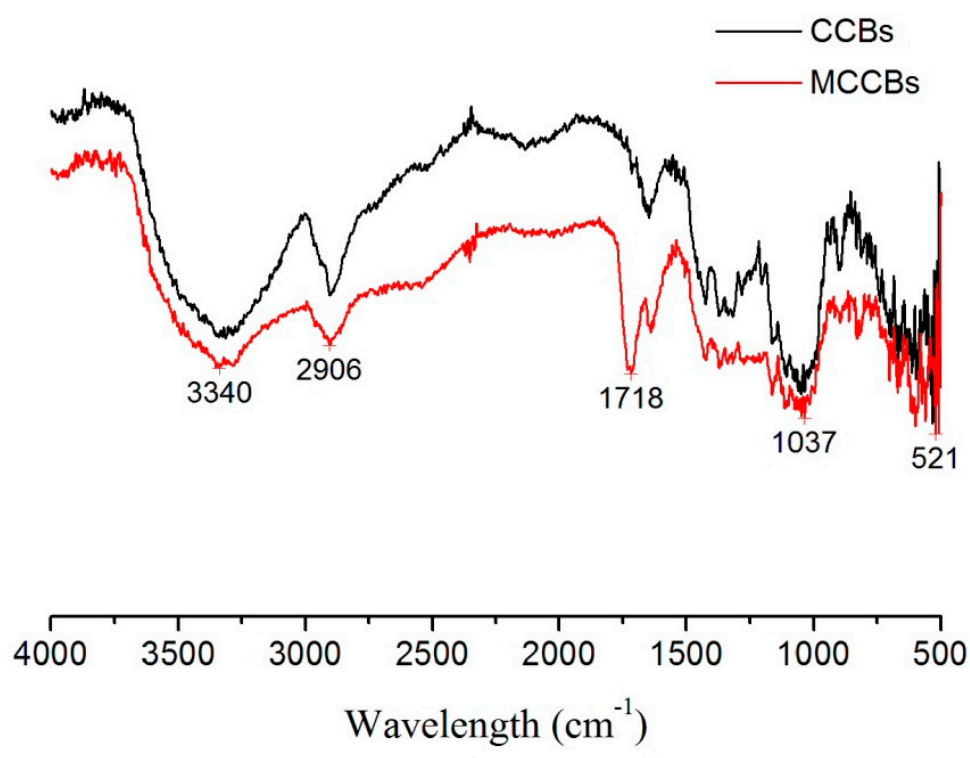

Figure 1. FT-IR of CCBs and MCCBs. 
The cross-section of MCCBs was observed using SEM; the results are shown in Figure 2. Multiple small hollow pockets were found in Figure 2, indicating that the beads with porous structure were obtained using the method described previously. The small hollow pockets were formed probably due to the generation and release of the $\mathrm{CO}_{2}$ originating from nano-sized calcium carbonate as a pore forming agent.

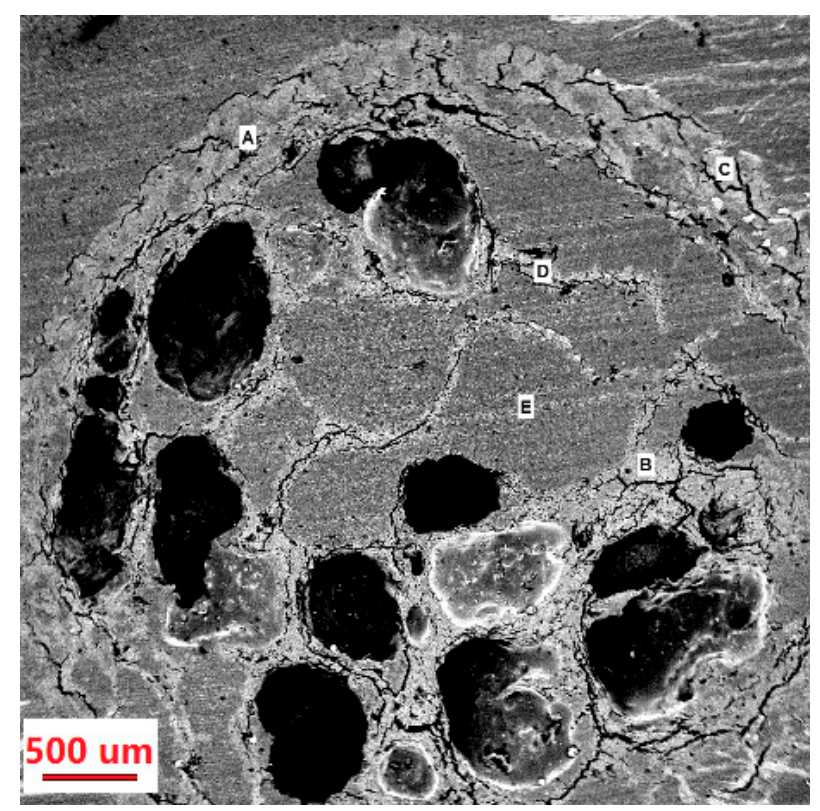

Figure 2. Scanning electron micrographs of cross-section MCCBs. A, B and C are cellulose; D and E are $\mathrm{CF}$.

\subsection{Optimum Laccase Immobilization Conditions}

\subsubsection{Effect of $\mathrm{pH}$ on Laccase Immobilization}

To research the effect of $\mathrm{pH}$ on the laccase immobilization, $10 \mathrm{mg}$ support was put into $8 \mathrm{~g} / \mathrm{L}$ laccase solutions with $\mathrm{pH}$ ranged from 3.0 to 7.0 at $25 \pm 1{ }^{\circ} \mathrm{C}$ and contact time was $2 \mathrm{~h}$. Generally, the strength of the acting force between the support and laccase during an adsorption process was decided by the charge properties of the support surface and the laccase molecule [26]. However, laccase enzyme shows different charge characteristics under different $\mathrm{pH}$ conditions, and the change of the electrostatic association will influence the recovered activity and laccase immobilization yield [27].

The immobilization yield was increased along with $\mathrm{pH}$ as shown in Figure 3. This is probably because when $\mathrm{pH}$ was higher than the laccase isoelectric point, laccase molecules and support were bridged by residual calcium ions. However, the recovered activity did not show a monotone increase trend, and the highest immobilized laccase recovered activity was achieved at $\mathrm{pH}$ 4.0. This result illustrated that $\mathrm{pH}$ significantly influenced the laccase activity, which agreed well with previous studies $[28,29]$. The laccase activity can be altered by varying $\mathrm{pH}$, which can change the configuration of protein [30,31]. Despite having a lower immobilization yield at $\mathrm{pH} 4.0$, the recovered activity of immobilization laccase showed a significant advantage, and thus $\mathrm{pH} 4.0$ was chosen in the following research. 


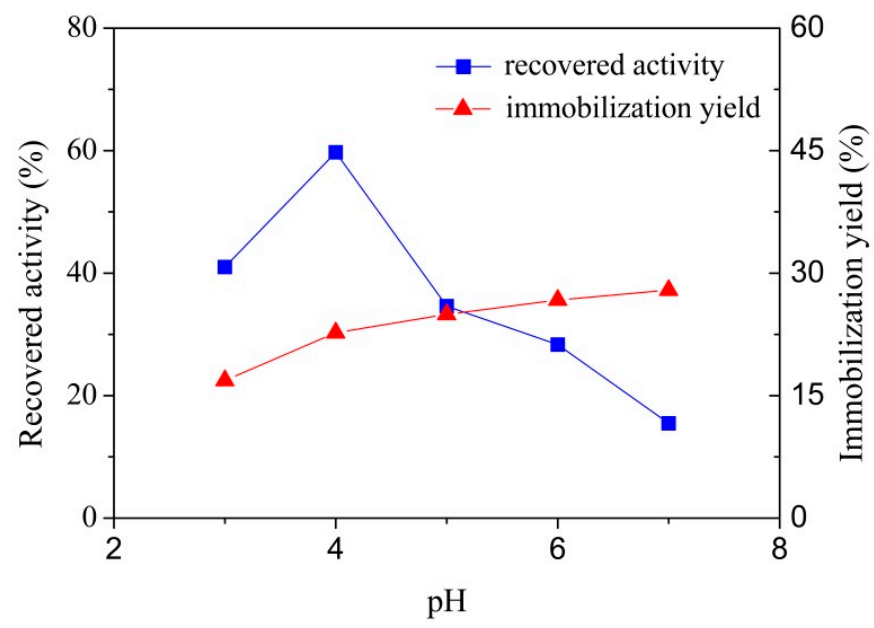

Figure 3. Effect of $\mathrm{pH}$ on immobilized laccase recovered activity and laccase immobilization yield by adsorption on MCCBs.

\subsubsection{Effect of Initial Enzyme Concentration on Laccase Immobilization}

To find the optimum enzyme concentration, different concentration of enzyme solutions were used to immobilize laccase in a set of experiments. Under the optimum conditions, i.e., $\mathrm{pH}=4$ and $T=25 \pm 1{ }^{\circ} \mathrm{C}$, contact time $2 \mathrm{~h}$, the effect of different enzyme concentrations on laccase immobilization yield was shown in Figure 4. The enzyme concentrations were varied from 0.5 to $32 \mathrm{~g} / \mathrm{L}$. As shown in Figure 4, the immobilization yield had a sharp increase with the increase of enzyme concentration and reached a high point at $16 \mathrm{~g} / \mathrm{L}$, followed by a slight increase as the concentration further increased to $32 \mathrm{~g} / \mathrm{L}$. This result indicated that the enzyme concentration has a significant effect on laccase immobilization yield, and high enzyme concentration had a promoting function on the reaction between laccase and the MCCBs support. This was because the high enzyme concentration could facilitate laccase to cover the entire surface of support, or even induce the multilayer adsorption [32]. Furthermore, this conclusion was in line with another study which considered that the incorporation of enzyme from solution onto support surface was clearly dependent on the enzyme concentration in solution [33].

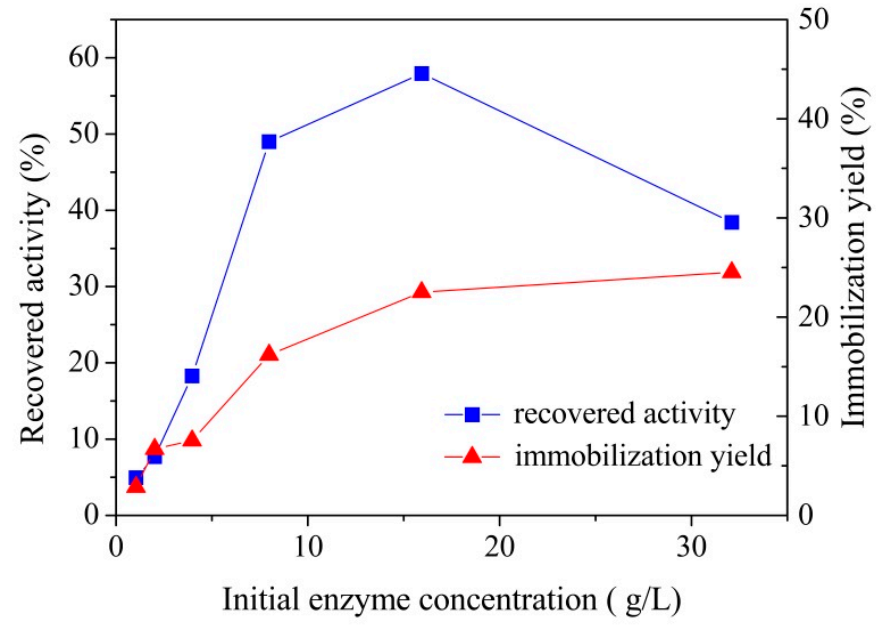

Figure 4. Effect of initial enzyme concentration on immobilized laccase recovered activity and laccase immobilization yield by absorption on MCCBs. 
On the other hand, the recovered activity of immobilized laccase was increased with increase of enzyme concentration and achieved the highest value at $16 \mathrm{~g} / \mathrm{L}$, which was consistent with the trend of immobilization yield, but the activity sharply decreased when the enzyme concentration further increased to $32 \mathrm{~g} / \mathrm{L}$. The highest recovered activity achieved at $16 \mathrm{~g} / \mathrm{L}$ indicated that probably the laccase molecule covered the entire support surface or adsorption reached the equilibrium at this concentration, and with the further increase of the enzyme concentration in solution, no more support surface would be available to adsorb laccase and the adsorption occurred between the first layer laccase and the laccase in solution [34]. In other words, when concentration was above $16 \mathrm{~g} / \mathrm{L}$, the excess laccase was loaded on top of other laccase to create multi-layer adsorpion. Under this condition, although more laccase was loaded on the support, the active sites of the first layer were covered by the second layer, which resulted in the decrease of recovered activity.

According to these results, the optimum initial enzyme concentration should be $16 \mathrm{~g} / \mathrm{L}$, since it was the best choice after overall consideration of immobilization yields and recovered activity. Above this point, although there was a slight increase of the immobilization yield, the recovered activity showed a clear decline.

\subsubsection{Effect of Contact Time on Laccase Immobilization}

Contact time is another important factor in laccase immobilization. The effect of contact time was evaluated by putting $10 \mathrm{mg}$ MCCBs into $16 \mathrm{~g} / \mathrm{L}$ laccase solution under $\mathrm{pH} 4.0, T=25 \pm 1{ }^{\circ} \mathrm{C}$ conditions. The contact time was set from 0.5 to $8 \mathrm{~h}$ and the effect of contact time on recovered activity and laccase loaded were showed in Figure 5.

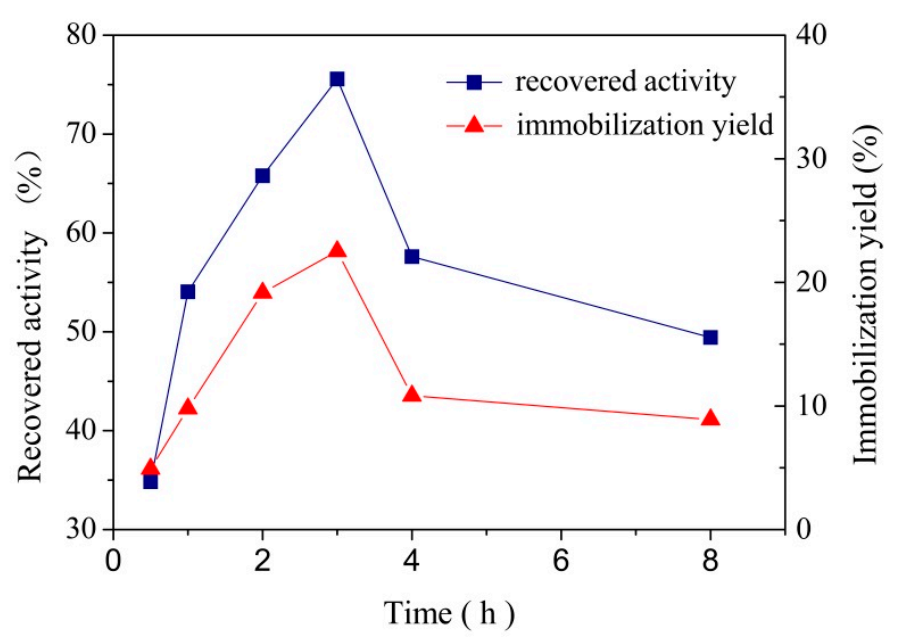

Figure 5. Effect of contact time on immobilized laccase recovered activity and laccase immobilization yield by absorption on MCCBs.

It was observed that the laccase immobilization yield increased with the increase of the contact time until $3 \mathrm{~h}$ and then showed a decline. This result illustrated that at $3 \mathrm{~h}$ the laccase reached the maximum adsorption. After $3 \mathrm{~h}$, the laccase immobilization yield decreased, probably because of desorption, and the same result was also found in other studies [32,35]. The curve of recovered activity changed in line with that of laccase immobilization yield. In general, there was a positive correlation between the laccase immobilization yield and recovered activity. So the highest recovered activity achieved at $3 \mathrm{~h}$ also confirmed that at this point the maximum adsorption load was reached. Based on the data mentioned above, it could be concluded that the optimum contact time was $3 \mathrm{~h}$ and there was no advantage to prolong the contact time. 


\subsection{EDS Analysis of Immobilized Laccase MCCBs}

The energy dispersive X-ray spectra (EDS) of the MCCBs and immobilized laccase MCCBs are presented in Figure 6. Compared to Figure 6A, P signal appeared in Figure 6B, indicating the presence of the laccase on the MCCBs.
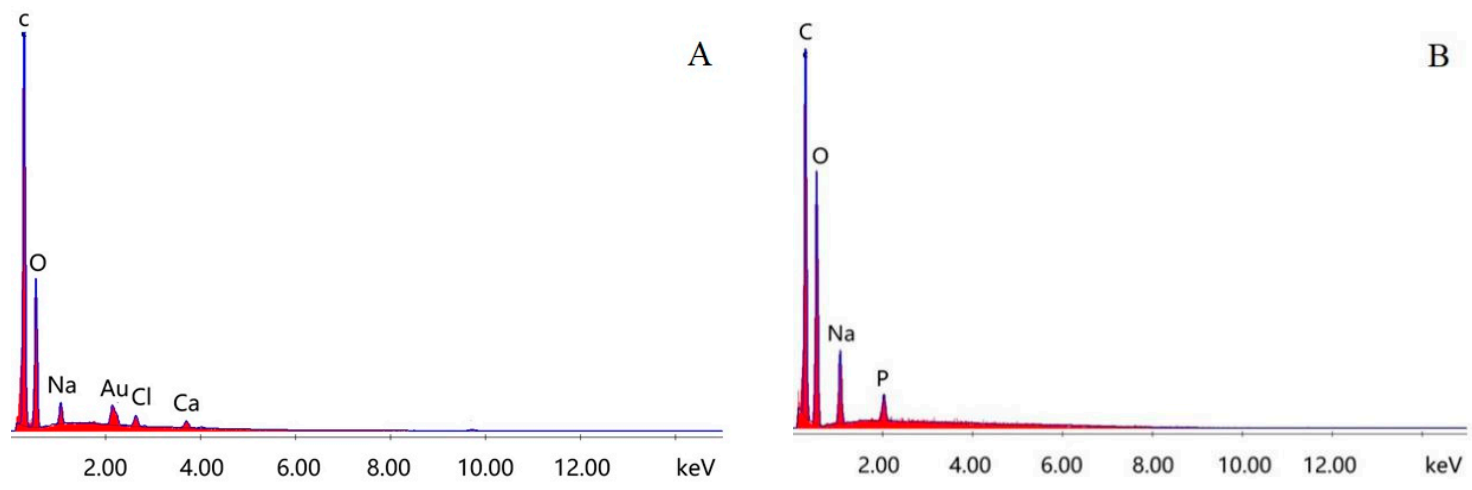

Figure 6. EDS spectra of the MCCBs (A) and immobilized laccase MCCBs (B).

\subsection{Thermal and Operational Stability of Immobilization Laccase}

The thermal and operational stabilities are the two most important parameters related to the application of the immobilized laccase. The thermal stability (left) and operational stability (right) are shown in Figure 7. To evaluate the thermal stability, the residual activities of free and immobilized laccase were measured at $60{ }^{\circ} \mathrm{C}$ for $6 \mathrm{~h}$. The immobilized laccase was obtained at the optimum experiment conditions: enzyme solution concentration $16 \mathrm{~g} / \mathrm{L}, \mathrm{pH} 4.0$ and contact time $3 \mathrm{~h}$. As can be seen from Figure 7 (left), the thermal stability of immobilized laccase is significantly higher comparing to that of free laccase at $60{ }^{\circ} \mathrm{C}$. At the end of the experiment, the immobilized laccase maintained $83 \%$ of its initial activity and only $56 \%$ was retained by free laccase. A similar result was also reported elsewhere [36]. The increase of immobilized laccase activity was due to the limited freedom of the immobilized laccase, which could decrease the chance of drastic conformational changes and increase the stability of the laccase [37]. Another possibility is that immobilization makes heated laccase, which has exposed its hydrophobic core, unlikely to form intermolecular aggregates [38].

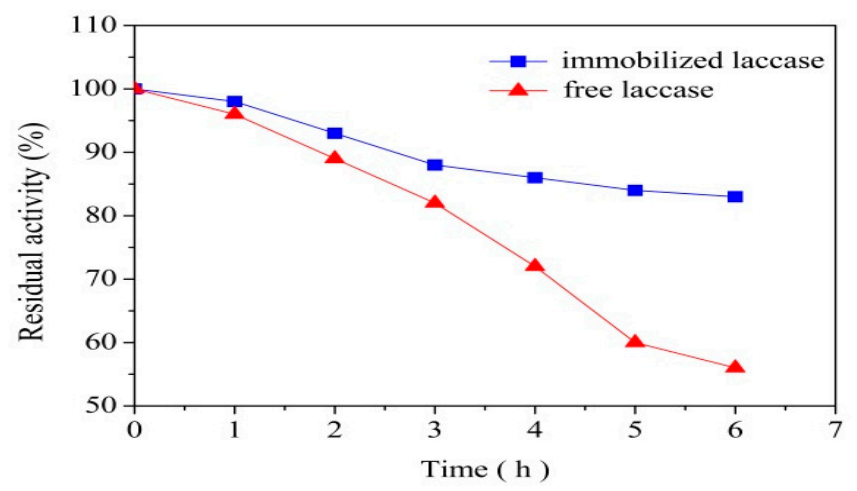

Figure 7. Thermal and operational stability of laccase immobilized on MCCBs by absorption at $\mathrm{pH} 4.0$, $16 \mathrm{~g} / \mathrm{L}$ initial lacasse concentration and $3 \mathrm{~h}$ contact time.

Compared to free laccase, reusability was an advantage of immobilized laccase, which has a great influence on cost saving. The immobilized laccase obtained at the optimum conditions was studied by cycles of ABTS oxidation, and 10 cycles were carried out to evaluate the operational stability. The results are shown in Figure 7 (right). After five cycles the immobilized laccase lost about $37 \%$ of 
initial activity. The loss of the activity was attributed to part of immobilized laccase with weak binding force desorbed from the MCCBs support during the washing process. After that, the residual activity showed a stable trend which retained about $60 \%$ of initial activity after six cycles. Although some results obtained in other studies were better than that in this work, which mainly because the support and immobilizing methods were different. Cellulose is a new kind of support in laccase immobilizing, and the performance identified in this work demonstrated that the laccase immobilized with MCCBs is of great potential for practical application.

\subsection{Degradation of PCBs by Immobilized Laccase}

The activity of MCCBs immobilized laccase in degrading PCBs was evaluated in this study and the removal rate is shown in Figure 8. As can be seen from Figure 8, the removal rate of HO-DiCB by immobilized laccase was about $85 \%$ whereas the result obtained in the control experiment was about $44 \%$. The degradation in the control experiment was probably due to the adsorption of HO-DiCB on MCCBs instead of biodegradation. The HO-DiCB transferred from the solution to the surface of the control resulted in the decrease of the concentration of the $\mathrm{HO}-\mathrm{DiCB}$; similar results of removing PCBs by adsorption methods were also reported by others $[39,40]$. The removal rate of immobilized laccase was obviously higher than that of control beads without laccase immobilized, indicating that HO-DiCB was effectively degraded by immobilized laccase. Moreover, considering the removal ability of the control beads, the high removal rate of the immobilized laccase probably resulted from both the enzymatic degradation and adsorption processes or synergetic effect of both processes. Although there were some researches on degrading PCBs by laccase, few results of removal rate had been reported yet. The result gained in this research illustrated that immobilizing laccase on MCCBs is promising for better degradation of PCBs. Clearly, a plateau occurred in the control curve, which might correspond to the maximum amount of HO-DiCB that can be absorbed onto MCCBs surface or inside pores. We simulated this dynamic curve with a two-reagent reaction model (Equation (4)) by fixing initial content of PCBs $\left(r_{0}\right)$ and adsorption capacity of MCCBs $\left(s_{0}\right)$ to 1 and 0.408 (the height of plateau) respectively, and reaction constant to 1 . The results indicated the excellent fitting qualitatively. The laccase catalyzed HO-DiCB concentration curve was fitted with the first-order reaction shown below:

$$
\begin{gathered}
t=1 / k \times 1 /\left(r_{0}-s_{0}\right) \times\left(\left(\ln \left(r_{0}-x\right) / r_{0}\right)-\ln \left(\left(s_{0}-x\right) / s_{0}\right)\right) \\
\ln (1-r)=A-k t
\end{gathered}
$$

where $r$ is the ratio of removal, $t$ is time, $k$ is reaction rate constant, and $A$ is an offset factor.

The curve fits this equation perfectly. While $A$ is supposed to be 0 when $r$ and $t$ both go to 0 , our fitting suggests that $A$ being zero introduced significant bias. This non-zero offset could be due to measurement uncertainty or residual adsorption. Noticeably, this linear curve did not show any turning point, indicating that laccase adsorption suppressed PCBs adsorption onto MCCBs due to covering of binding sites and PCBs degradation. 




Figure 8. Removal rate of HO-DiCB by immobilized laccase and control (CCBs without laccase) at $\mathrm{pH}$ 4.0 room temperature; inlet: $\ln (1-r)$ vs. $t$ plot of curve for immobilized laccase.

\section{Conclusions}

A novel type of support beads (MCCBs), prepared by maleic anhydride-modified cellulose and nano $\mathrm{CaCO}_{3}$ powder as pore forming agent, was successfully produced and used to immobilize laccase in attempt to degrade HO-DiCB. The MCCBs showed excellent performance in terms of the immobilization yield and the recovered activity when used to immobilize commercial laccase. The immobilized laccase was reusable and maintained high residual activity, leading to the very efficient degradation of HO-DiCB. As green-based material, MCCBs can be considered as an appropriate support for immobilizing laccase, and the technology developed in this work has a potential advantage in removal PCBs in wastewater.

Author Contributions: N.L. and H.X. designed the experiments. N.L. carried out the experiment with the help of Q.X., X.H. and Y.L., M.N. and Q.P. analysed the data. All authors discussed the results, and wrote the the manuscript.

Funding: Foundation (No. KF201622) of Key Laboratory of Pulp and Paper Science and Technology of Ministry of Education/Shandong Province of China, China Ministry of Education (KLIEEE-16-04), NSF China (\#51379077), NSERC Canada and China Scholarship Council.

Conflicts of Interest: The authors declare no competing interests.

\section{References}

1. Robertson, L.W.; Hansen, L.G. PCBs: Recent Advances in Environmental Toxicology and Health Effects; University Press of Kentucky: Lexington, KY, USA, 2015.

2. Balmer, B.C.; Ylitalo, G.M.; Mcgeorge, L.E.; Baugh, K.L.; Boyd, D.; Mullin, K.D.; Rosel, P.E.; Sinclair, C.; Wells, R.S.; Zolman, E.S. Persistent organic pollutants (POPs) in blubber of common bottlenose dolphins (Tursiops truncatus) along the northern Gulf of Mexico coast. Sci. Total Environ. 2015, 527-528, 306-312. [CrossRef] [PubMed]

3. Urai, M.; Yoshizaki, H.; Anzai, H.; Ogihara, J.; Iwabuchi, N.; Harayama, S.; Sunairi, M.; Nakajima, M. Structural analysis of an acidic, fatty acid ester-bonded extracellular polysaccharide produced by a pristane-assimilating marine bacterium, Rhodococcus erythropolis PR4. Carbohydr. Res. 2007, 342, 933-942. [CrossRef]

4. Ballinas-Casarrubias, L.; Villanueva-Solís, L.; Espinoza-Hicks, C.; Camacho-Dávila, A.; Castillo, H.A.P.; Pérez, S.B.; Villa, E.D.; Hernández, M.D.D.; González-Sánchez, G. Effect of Laccase-Mediated Biopolymer Grafting on Kraft Pulp Fibers for Enhancing Paper's Mechanical Properties. Polymers 2017, 9, 570. [CrossRef] 
5. Sarma, R.; Islam, M.S.; Running, M.P.; Bhattacharyya, D. Multienzyme Immobilized Polymeric Membrane Reactor for the Transformation of a Lignin Model Compound. Polymers 2018, 10, 463. [CrossRef]

6. Luna-Acosta, A.; Bustamante, P.; Budzinski, H.; Huet, V.; Thomas-Guyon, H. Persistent organic pollutants in a marine bivalve on the Marennes-Oléron Bay and the Gironde Estuary (French Atlantic Coast)—Part 2: Potential biological effects. Sci. Total Environ. 2015, 514, 511-522. [CrossRef]

7. Hou, J.; Dong, G.; Ye, Y.; Chen, V. Laccase immobilization on titania nanoparticles and titania-functionalized membranes. J. Membr. Sci. 2014, 452, 229-240. [CrossRef]

8. Bautista, L.F.; Morales, G.; Sanz, R. Biodegradation of polycyclic aromatic hydrocarbons (PAHs) by laccase from Trametes versicolor covalently immobilized on amino-functionalized SBA-15. Chemosphere 2015, 136, 273-280. [CrossRef]

9. Kim, J.H.; Hong, S.-G.; Sun, H.J.; Ha, S.; Kim, J. Precipitated and chemically-crosslinked laccase over polyaniline nanofiber for high performance phenol sensing. Chemosphere 2016, 143, 142-147. [CrossRef] [PubMed]

10. Datta, S.; Christena, L.R.; Rajaram, Y.R.S. Enzyme immobilization: An overview on techniques and support materials. Biotech 2013, 3, 1-9. [CrossRef]

11. Huber, D.; Pellis, A.; Daxbacher, A.; Nyanhongo, G.S.; Guebitz, G.M. Polymerization of Various Lignins via Immobilized Myceliophthora thermophila Laccase (MtL). Polymers 2016, 8, 280. [CrossRef]

12. Nasatto, P.L.; Pignon, F.; Silveira, J.L.; Duarte, M.E.R.; Noseda, M.D.; Rinaudo, M. Methylcellulose, a cellulose derivative with original physical properties and extended applications. Polymers 2015, 7, 777-803. [CrossRef]

13. Paul, U.C.; Fragouli, D.; Bayer, I.S.; Athanassiou, A. Functionalized cellulose networks for efficient oil removal from oil-water emulsions. Polymers 2016, 8, 52. [CrossRef]

14. Zubik, K.; Singhsa, P.; Wang, Y.; Manuspiya, H.; Narain, R. Thermo-responsive poly(N-isopropylacrylamide)cellulose nanocrystals hybrid hydrogels for wound dressing. Polymers 2017, 9, 119. [CrossRef]

15. Pan, Y.; Farmahini-Farahani, M.; O’Hearn, P.; Xiao, H.; Ocampo, H. An overview of bio-based polymers for packaging materials. J. Bioresour. Bioprod. 2016, 1, 106-113.

16. Wu, X.; Zhao, F.; Varcoe, J.R.; Thumser, A.E.; Avignone-Rossa, C.; Slade, R.C. Direct electron transfer of glucose oxidase immobilized in an ionic liquid reconstituted cellulose-carbon nanotube matrix. Bioelectrochemistry 2009, 77, 64-68. [CrossRef]

17. Kim, H.J.; Jin, J.N.; Kan, E.; Kim, K.J.; Sang, H.L. Bacterial cellulose-chitosan composite hydrogel beads for enzyme immobilization. Biotechnol. Bioprocess Eng. 2017, 22, 89-94. [CrossRef]

18. Frazão, C.J.R.; Silva, N.H.C.; Freire, C.S.R.; Silvestre, A.J.D.; Xavier, A.M.R.B.; Tavares, A.P.M. Bacterial cellulose as carrier for immobilization of laccase: Optimization and characterization. Eng. Life Sci. 2015, 14, 500-508. [CrossRef]

19. Sathishkumar, P.; Kamala-Kannan, S.; Min, C.; Kim, J.S.; Hadibarata, T.; Salim, M.R.; Oh, B.T. Laccase immobilization on cellulose nanofiber: The catalytic efficiency and recyclic application for simulated dye effluent treatment. J. Mol. Catal. B Enzym. 2014, 100, 111-120. [CrossRef]

20. Moccelini, S.K.; Franzoi, A.C.; Vieira, I.C.; Dupont, J.; Scheeren, C.W. A novel support for laccase immobilization: Cellulose acetate modified with ionic liquid and application in biosensor for methyldopa detection. Biosens. Bioelectron. 2011, 26, 3549-3554. [CrossRef] [PubMed]

21. Li, Y.; Xiao, H.; Chen, M.; Song, Z.; Zhao, Y. Absorbents based on maleic anhydride-modified cellulose fibers/diatomite for dye removal. J. Mater. Sci. 2014, 49, 6696-6704. [CrossRef]

22. Li, Y.; Xiao, H.; Pan, Y.; Wang, L. Novel Composite Adsorbent Consisting of Dissolved Cellulose Fiber/Microfibrillated Cellulose for Dye Removal from Aqueous Solution. ACS Sustain. Chem. Eng. 2018, 6, 6994-7002. [CrossRef]

23. Chen, Y.; Zhu, H.; Xiong, J.; Zhang, C.; Li, Y. Preparation and application of novel chitosan-cellulose composite materials to adsorb $\mathrm{Pb}$ (II) and $\mathrm{Cr}$ (VI) ions from water. J. Bioresour. Bioprod. 2017, 2, 175-183.

24. Eggert, C.; Temp, U.; Eriksson, K.-E. The ligninolytic system of the white rot fungus Pycnoporus cinnabarinus: Purification and characterization of the laccase. Appl. Environ. Microbiol. 1996, 62, 1151-1158.

25. Bradford, M.M. A rapid and sensitive method for the quantitation of microgram quantities of protein utilizing the principle of protein-dye binding. Anal. Biochem. 1976, 72, 248-254. [CrossRef]

26. Skoronski, E.; Souza, D.H.; Ely, C.; Broilo, F.; Fernandes, M.; Fúrigo, A.; Ghislandi, M.G. Immobilization of laccase from Aspergillus oryzae on graphene nanosheets. Int. J. Biol. Macromol. 2017, 99, 121-127. [CrossRef] [PubMed] 
27. Vishnu, D.; Neeraj, G.; Swaroopini, R.; Shobana, R.; Kumar, V.V.; Cabana, H. Synergetic integration of laccase and versatile peroxidase with magnetic silica microspheres towards remediation of biorefinery wastewater. Environ. Sci. Pollut. Res. 2017, 24, 17993-18009. [CrossRef]

28. $\mathrm{Xu}, \mathrm{F}$. Effects of redox potential and hydroxide inhibition on the $\mathrm{pH}$ activity profile of fungal laccases. J. Biol. Chem. 1997, 272, 924-928. [CrossRef] [PubMed]

29. Johannes, C.; Majcherczyk, A. Laccase activity tests and laccase inhibitors. J. Biotechnol. 2000, 78, 193-199. [CrossRef]

30. Bonomo, R.; Cennamo, G.; Purrello, R.; Santoro, A.; Zappala, R. Comparison of three fungal laccases from Rigidoporus lignosus and Pleurotus ostreatus: Correlation between conformation changes and catalytic activity. J. Inorg. Biochem. 2001, 83, 67-75. [CrossRef]

31. Rodakiewicz-Nowak, J.; Kasture, S.; Dudek, B.; Haber, J. Effect of various water-miscible solvents on enzymatic activity of fungal laccases. J. Mol. Catal. B Enzym. 2000, 11, 1-11. [CrossRef]

32. Cristóvão, R.O.; Tavares, A.P.; Brígida, A.I.; Loureiro, J.M.; Boaventura, R.A.; Macedo, E.A.; Coelho, M.A.Z. Immobilization of commercial laccase onto green coconut fiber by adsorption and its application for reactive textile dyes degradation. J. Mol. Catal. B Enzym. 2011, 72, 6-12. [CrossRef]

33. Bautista, L.F.; Morales, G.; Sanz, R. Immobilization strategies for laccase from Trametes versicolor on mesostructured silica materials and the application to the degradation of naphthalene. Bioresour. Technol. 2010, 101, 8541-8548. [CrossRef]

34. De Oliveira, P.C.; Alves, G.M.; de Castro, H.F. Immobilisation studies and catalytic properties of microbial lipase onto styrene-divinylbenzene copolymer. Biochem. Eng. J. 2000, 5, 63-71. [CrossRef]

35. Tavares, A.P.; Silva, C.G.; Dražić, G.; Silva, A.M.; Loureiro, J.M.; Faria, J.L. Laccase immobilization over multi-walled carbon nanotubes: Kinetic, thermodynamic and stability studies. J. Colloid Interface Sci. 2015, 454, 52-60. [CrossRef] [PubMed]

36. Tavares, A.P.; Rodríguez, O.; Fernández-Fernández, M.; Domínguez, A.; Moldes, D.; Sanromán, M.A.; Macedo, E.A. Immobilization of laccase on modified silica: Stabilization, thermal inactivation and kinetic behaviour in 1-ethyl-3-methylimidazolium ethylsulfate ionic liquid. Bioresour. Technol. 2013, 131, 405-412. [CrossRef] [PubMed]

37. Al-Adhami, A.J.; Bryjak, J.; Greb-Markiewicz, B.; Peczyńska-Czoch, W. Immobilization of wood-rotting fungi laccases on modified cellulose and acrylic carriers. Process Biochem. 2002, 37, 1387-1394. [CrossRef]

38. Steffensen, C.L.; Andersen, M.L.; Degn, P.E.; Nielsen, J.H. Cross-linking proteins by laccase-catalyzed oxidation: Importance relative to other modifications. J. Agric. Food Chem. 2008, 56, 12002-12010. [CrossRef] [PubMed]

39. Nollet, H.; Roels, M.; Lutgen, P.; Van der Meeren, P.; Verstraete, W. Removal of PCBs from wastewater using fly ash. Chemosphere 2003, 53, 655-665. [CrossRef]

40. Choi, H.; Al-Abed, S.R.; Agarwal, S.; Dionysiou, D.D. Synthesis of reactive nano-Fe/Pd bimetallic system-impregnated activated carbon for the simultaneous adsorption and dechlorination of PCBs. Chem. Mater. 2008, 20, 3649-3655. [CrossRef]

(C) 2018 by the authors. Licensee MDPI, Basel, Switzerland. This article is an open access article distributed under the terms and conditions of the Creative Commons Attribution (CC BY) license (http:/ / creativecommons.org/licenses/by/4.0/). 